\title{
Effect of Moisture Content and Inner Drum Rotation Speed on the Shelling Performance of A Melon Sheller
}

\author{
Oluwole O. O*, Adedeji A. S \\ Mechanical Engineering Department, University of Ibadan
}

\begin{abstract}
Melon shelling is an intermediate stage in melon processing and needs to be given much attention for most of the farmers still employ manual means of shelling which is time consuming, energy demanding and resulting in low income. A melon shelling machine using a rubbing action motion in peeling was designed and fabricated. The machine which is powered by $1 \mathrm{Hp}, 1400 \mathrm{rpm}$ electric motor consists of a hopper, the shelling chamber (rotating inner serrated drum and a fixed cylindrical ring), an outlet unit, and a motor seat. An inner drum rotation speed of 350rpm was achieved through the use of a big driven pulley to obtain an appreciable shelling performance of $58.68 \%$ with percentage loss of $16.5 \%$ at percentage moisture content of $23.08 \%$.
\end{abstract}

Keywords Melon, Shelling, Shelling Performance

\section{Introduction}

Melon Citrullus valgaris is one of the most important vegetable crops in the tropical and sub-tropical regions of the world. Melon is widely called 'Egusi' by Yorubas, 'Agusi' by Hausas and 'Ogil' by Igbo people of Nigeria. Cultivation of 'Egusi' melon is across the country but with higher intensity in Kogi state of Nigeria. There was large increase in land area put to melon production in 2004 and 2005(Lagoke et al., 1983). Melon is usually grown in mixture with other crops such as Cassava, Yam and Maize which may account for the increase in land area put to its production. The mesocarp of the fruit is extremely bitter, but the seeds are important sources of Vitamin E and it is rich in Proteins and Oils which can be extracted for cooking purposes. A valuable vegetable Oil extracted from the seed, while the ground seed is used to prepare various delicacies including cake and soup (Lagoke et al., 1983). 'Egusi' melon is important for their seeds in Sudan and Ethiopia, and the extracted yellow oil in high demand.

Melon seed contains about $314 \mathrm{gKg}-1 \mathrm{DM}$ crude protein, $439.3 \mathrm{gKg}-1 \mathrm{DM}$ crude fat, $31.4-90.6 \mathrm{gKg}-1 \mathrm{DM}$ crude fibre, 2.4 - 4.6 gKg-1DM phosphorus, $3.9-6.5$ gKg-1DM potassium and $4.1-5.9 \mathrm{McalKg}-1 \mathrm{DM}$ energy (Enujuigha and Ayodele, 2003). The seeds are small, flat and partly oval in shape, containing cotyledons and it is an annual crop. The cotyledons are rich in protein $(40 \%)$ and edible oil $(60 \%)$. Oils can be extracted for cooking purposes, the

* Corresponding author:

lekeoluwole@gmail.com (oluleke oluwole)

Published online at http://journal.sapub.org/scit

Copyright (C) 2012 Scientific \& Academic Publishing. All Rights Reserved seeds can be ground into a powder and used as a soup thickener or flavouring agent (Badifu and Ogunsua, 1991) and the ground seed is also used to prepare delicacies like cake.

Shelling can be defined as a process by which husk (outer shell) is removed from a seed to expose cotyledon. Shelling can be done both manually (by hand) and mechanically (melon sheller). Manual method is a traditional means of shelling, it does not encourage higher productivity, time consuming and consumes more energy. Manual methods are of two types:

(1) Picking and shelling

(2) Bagging and shelling

This crude method is now being mechanized through introduction of melon sheller. Perfect shelling is obtained by investigating and controlling the properties of the melon seeds which include; hardness, thickness and seed moisture content.

Agricultural mechanization operation is of age and a lot of work has been done to make the operation easier in different post harvest processing; An attempt was made on mellon seed shelling by Makanjuola, 1972 where the seeds were shelled by moving between vanes on a rotating impeller and making an impact on a fixed cylindrical ring. Here, the bending properties of melon seeds when compressed between two parallel plates under static loading were studied.

Another attempt was made by Adekunle et al, 2009 using the same principle of impacting but on a stationary abrasive cylinder. Using this principle, a melon sheller with rotating impeller vanes was designed with the angle of release, machine speed, and impact force of $30^{\circ}, 980 \mathrm{rpm}$ and $0.367 \mathrm{~N}$ respectively. Though the efficiency derived was about $17 \%$. 
Oladejo, 2010 also working on melon shelling using the principle of seed impacting on a stationary outer drum obtained an efficiency of about $47 \%$ using an angle of release, machine speed and impact force of $45^{\circ}, 1530 \mathrm{rpm}$ and $0.537 \mathrm{~N}$ respectively. The present work describes the use of a rubbing action motion as opposed to the use of impact force to shell melon seeds.

\section{Design of the Melon Sheller}

\subsection{Machine Description}

The Machine is basically divided into four main parts which are: Hopper, Shelling Unit, Outlet Unit, Power Unit.

HOPPER: This is a square shaped structure with cavity through which melon seeds pass into the shelling unit. It is made of mild steel plate of thickness $2 \mathrm{~mm}$. It has an upper dimension of $292.1 \mathrm{~mm}$ by $292.1 \mathrm{~mm}$ and cavity dimension of $101.6 \mathrm{~mm}$ by $101.6 \mathrm{~mm}$.

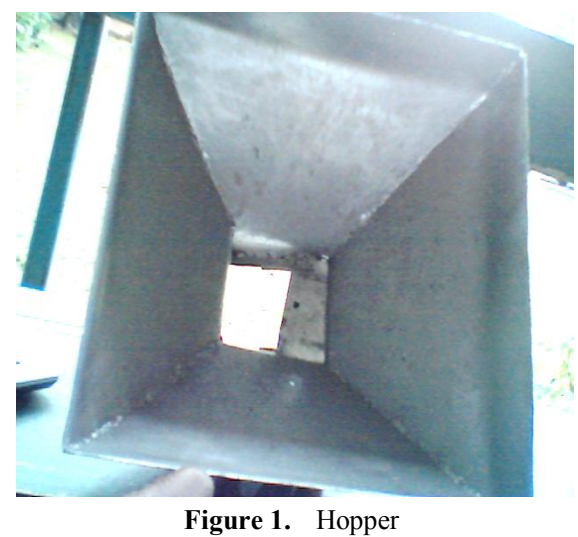

(1) A shaft for rotating the inner drum which is made of mild steel rod.

(2) Power Unit: This consists of a V belt used to transmit power from the electric motor to the shelling unit.

(3) Shelling Unit: This consists of a rotating inner drum having diameter $254 \mathrm{~mm}$, height $292.1 \mathrm{~mm}$ and with slant vanes at an angle $30^{\circ}$, and fixed cylindrical ring of diameter $292.1 \mathrm{~mm}$, height $292.4 \mathrm{~mm}$ also containing fixed vanes situated in a cylindrical shaped casing.

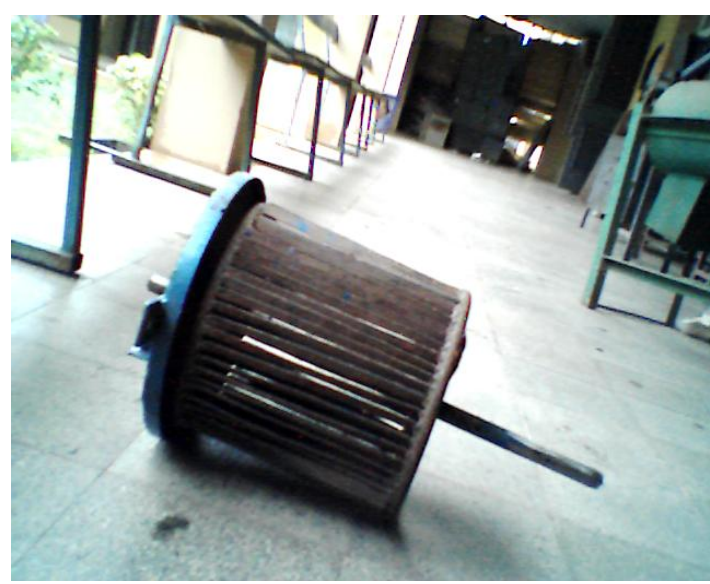

Figure 2. Inner drum

\subsection{Operation of the Machine}

Shelling is an intermediate stage in melon processing. It is a post-harvest process. Melon seeds are removed from melon balls, washed, and dried. The quality of melon seeds produced is a factor of the soil type, melon variety and cultivation care applied before harvesting. The Melon sheller contains a rotating inner drum moving at a certain speed received from an electric motor sufficient enough to generate a force whose magnitude is high enough to shell the melon seeds. The seeds that are free from dirt, feed slowly and steadily through the hopper into the shelling unit where the seeds move between a rotating inner drum and a fixed cylindrical ring that encloses the drum. Shelling force is a rubbing action experienced by the melon seeds when impinged upon by the rod weldments on the serrations on the inner drum with the rotating inner drum before getting down the outlet cavity. Because of this force, some seeds are broken, which leads to seeds deterioration during storage and make for low market value.

\section{Design Considerations}

The following equations were used to design the components of the Shelling Machine.

\subsection{Power Requirement}

Total power required is calculated using equations as specified by Akintunde et al, 2005

$$
P_{T}=P_{\text {inner drum }}+P_{\text {shaft }}+P_{\text {shelling }}
$$

Pshelling is negligible since seeds are not resident in sheller but flow through in pieces.

Therefore, $P_{T}=P_{\text {inner drum }}+P_{\text {shaft }}$

but shaft and inner drum are welded together, so

$P_{T}=P_{\text {inner drum with shaft }}$

$P_{\text {inner drum with shaft }}$

$$
\begin{aligned}
& =T_{\text {inner }} \text { drum with shaft } \\
& \times V_{\text {inner }} \text { drum with shaft }
\end{aligned}
$$

$$
V_{\text {inner drum with shaft }}=\frac{2 \pi N}{60} \mathrm{~m} / \mathrm{s}
$$

$T_{\text {inner drum with shaft }}$ is the torque $(\mathrm{Nm})$

$N$ is the number of revolution per minute of inner drum with shaft $=350 \mathrm{rpm}$

$T_{\text {inner drum with shaft }}=$

mass $\times$ acceleration due to gravity $\times$ radial distance

$$
\text { mass }=5.6 \mathrm{~kg}
$$

radial distance $R=0.127 \mathrm{~m}$

acceleration due to gravity $=10 \mathrm{~m} / \mathrm{s}^{2}$

$T_{\text {inner drum with shaft }}=5.6 \times 10 \times 0.127$

$$
=7.112 \mathrm{Nm}
$$

$$
\begin{aligned}
& P_{\text {inner drum with shaft }}=7.112 \times \frac{2 \times 3.142 \times 350}{60 \times 1000} \\
= & 0.2607 \mathrm{KW}=0.349 \mathrm{Hp}
\end{aligned}
$$


Using the factor of safety of 2, power required is $0.70 \mathrm{Hp}$, therefore a motor of $1 \mathrm{Hp}$ is chosen to power the inner drum, shaft and shell the seeds.

\subsection{Analysis of Driven and Driving Pulley}

The diameter of driving pulley selected, D1 $=50.0 \mathrm{~mm}$

If the outside diameter of the driven pulley is four times that of the driving pulley, using the ratio;

$N_{1}=4 N_{2}$

$$
N_{1} D_{1}=N_{2} D_{2}
$$

$$
\frac{N_{1}}{N_{2}}=4
$$

But $N_{1}=1400 \mathrm{rpm}$ as seen on $1.0 \mathrm{Hp}(746 \mathrm{~W})$ electric motor.

$N_{2}=350 \mathrm{rpm}$

$$
N_{2}=\frac{1400}{4}
$$

From $N_{1} D_{1}=N_{2} D_{2}$

$$
D_{2}=\frac{1400 \times 50}{350}
$$

$D_{2}=200 \mathrm{~mm}$

To obtain speed of driving and driven pulley

$V_{1}=\frac{\pi D_{1} N_{1}}{60}$,

and

Where

$$
V_{2}=\frac{\pi D_{2} N_{2}}{60}
$$

$N_{1}$ and $N_{2}$ are the revolutions per minute for the driving pulley and driven pulley respectively.

$V_{1}$ and $V_{2}$ are the speed $(\mathrm{m} / \mathrm{s})$ of the driving pulley and driven pulley respectively.

$\mathrm{V}_{1}=3665.67 \mathrm{~mm} / \mathrm{s}$

$$
V_{1}=\frac{3.142 \times 1400 \times 50}{60}
$$

$\mathrm{V}_{1}=3.67 \mathrm{~m} / \mathrm{s}$

Speed of driven pulley;

$V_{2}=3665.67 \mathrm{~mm} / \mathrm{s}$

$$
V_{2}=\frac{3.142 \times 200 \times 350}{60}
$$

$V_{2}=3.67 \mathrm{~m} / \mathrm{s}$

Since there is no slip, $V_{1}=V_{2}=3.67 \mathrm{~m} / \mathrm{s}$

\subsection{Wrap Angles Determination}

Equations as expressed by Akintunde et al, 2005 were used;

$\propto_{1}=180-2 \sin ^{-1}\left(\frac{D_{2}-D_{1}}{2 C}\right)$ and

$\propto_{2}=180+2 \sin ^{-1}\left(\frac{D_{2}-D_{1}}{2 C}\right)$

$\propto_{1}=180-2 \sin ^{-1}\left(\frac{200-50}{2 \times 620}\right)$

$\propto_{2}=180+2 \sin ^{-1}\left(\frac{200-50}{2 \times 620}\right)$

Where: $\alpha_{1}=$ the angle of wrap for driving pulley (rad)

$\alpha_{2}=$ the angle of wrap for driven pulley.

$\mathrm{C}=$ center to center distance between driving

pulley and driven pulley $(\mathrm{mm})=620 \mathrm{~mm}$

$$
\propto_{1}=168.23^{\circ} \propto_{1}=2.94 \mathrm{rad}
$$

$$
\propto_{2}=191.77^{\circ} \propto_{2}=3.35 \mathrm{rad}
$$

\subsection{Determination of Belt Tensions}

$P=\left(T_{1}-T_{2}\right) V \quad$ (Akintunde et al, 1983)

where, $\mathrm{P}=$ belt power $(\mathrm{W}) ; \mathrm{V}=$ belt speed $(\mathrm{m} / \mathrm{s})$

$\mathrm{T} 1$ and $\mathrm{T} 2$ are tensions on the tight and slack sides respectively $(\mathrm{N})$

But $P=1.0 \mathrm{Hp}=746$ and, $\mathrm{V}=3.67 \mathrm{~m} / \mathrm{s}$

Thus, $\left(T_{1}-T_{2}\right)=203.27 \mathrm{~N}$

Using belt ratio for an open belt;

$\left(T_{1} / T_{2}\right)=e^{f \propto} \quad$ (Akintunde et al, 2005)

Where, $\mathrm{f}=$ coefficient of friction between belt and pulley

For mild steel pulley and rubber belt, $\mathrm{f}=0.30$ (khurma and Gupta, 2005)

$\frac{T_{1}}{T_{2}}=e^{0.30 \times 2.94}$

$$
\begin{aligned}
& \frac{T_{1}}{T_{2}}=e^{0.881} \\
& T_{1}=2.4 T_{2} \\
& T_{2}=145.19 \mathrm{~N} \\
& T_{1}=348.46 \mathrm{~N}
\end{aligned}
$$

\subsection{Determination of Shaft Torque and Permissible Angle of Twist}

The torque $M_{E}$ is determined as follows:

$M_{E}=\frac{\left(T_{1}-T_{2}\right) D_{2}}{2}$

Where, D2 is the diameter of the driven pulley and the twist caused by this torque on the shaft is given by Akintunde et al, 1983;

$$
\theta=\frac{584 M_{E} L}{G D^{4}}
$$

Where $\mathrm{D}$ here is the diameter of the shaft

$\mathrm{T}_{1}=$ tension on the tight side of the belt

$\mathrm{T}_{2}=$ tension on the slack side of the belt

$M_{E}=$ permissible angle of twist.

$\mathrm{G}=$ rigidity modulus of the shaft

$\mathrm{L}=$ length of the shaft $=508 \mathrm{~mm}$

Diameter of the shaft, $\mathrm{D}=0.03 \mathrm{~m}$

$\mathrm{G}=84 \times 10^{9}$ (Constant)

$\mathrm{T}_{2}=145.19 \mathrm{~N}$ and $\mathrm{T}_{1}=348.46 \mathrm{~N}$

$\mathrm{D}_{2}=200 \mathrm{~mm}=0.2 \mathrm{~m}$

Thus, $M_{E}=20.33 \mathrm{Nm} \quad$ and $\quad \theta=0.07^{\circ} / \mathrm{m}$

Note that the maximum permissible angle of twist $=$ $0.3^{\circ} / \mathrm{m}$. Therefore, the choice of a $30 \mathrm{~mm}$ diameter shaft is good for the design and can transmit the Torque without damage.

\subsection{Performance Test}

20 different samples of melon weighing $20 \mathrm{~g}$ each were weighed, soaked with different amounts of water and for different soaking times in order to determine best soaking time for shelling performance. Final weights were obtained after soaking before loading into the shelling unit.

Another 5 different samples of melon $20 \mathrm{~g}$ each were subjected to different moisture contents but fixed soaking 
time. Effect of moisture content and inner drum rotation speed on shelling performance was determined. Moisture content was calculated using ASAE standard S.352 (ASAE, 1982).

The shelling Performance of the machine was calculated thus;

\section{Shelling performance}

$=\frac{\text { total mass of shelled melon }}{\text { total mass received from outlet chute }} \times 100 \%$

Percentage loss was also evaluated thus,

$$
\% \text { loss }=\frac{\text { mass of broken seeds }}{\text { total input }} \times 100 \%
$$

\section{Results and Discussions}

\subsection{Determination of Soaking Time}

The results for the determination of soaking time are shown in Tables 1(a)-(e). The results showed that 7 minutes soaking time gave best shelling performance.

Table 1a. Shelling performance variation with time using $2.5 \mathrm{ml}$ added water.

\begin{tabular}{c|c|c|c}
\hline $\begin{array}{c}\text { Mellon } \\
\operatorname{mass}(\mathrm{g})\end{array}$ & $\begin{array}{c}\text { Water added } \\
(\mathrm{ml})\end{array}$ & $\begin{array}{c}\text { Time of soaking } \\
(\mathrm{min})\end{array}$ & $\begin{array}{c}\text { Shelling } \\
\text { performance }\end{array}$ \\
\hline 20 & 2.5 & 5 & $39 \%$ \\
20 & 2.5 & 7 & $40 \%$ \\
20 & 2.5 & 10 & $33.87 \%$ \\
20 & 2.5 & 15 & $42.59 \%$ \\
\hline
\end{tabular}

Table 1b. Shelling performance variation with time using $5.0 \mathrm{ml}$ added water.

\begin{tabular}{c|c|c|c}
\hline $\begin{array}{c}\text { Melon Mass } \\
(\mathrm{g})\end{array}$ & $\begin{array}{c}\text { Water added } \\
(\mathrm{ml})\end{array}$ & $\begin{array}{c}\text { Time of soaking } \\
(\mathrm{min})\end{array}$ & $\begin{array}{c}\text { Shelling } \\
\text { performance }\end{array}$ \\
\hline 20 & 5.0 & 5 & $38.24 \%$ \\
20 & 5.0 & 7 & $41.43 \%$ \\
20 & 5.0 & 10 & $46.43 \%$ \\
20 & 5.0 & 15 & $41.30 \%$ \\
\hline
\end{tabular}

Table 1c. Shelling performance variation with time using $7.5 \mathrm{ml}$ added water.

\begin{tabular}{c|c|c|c}
\hline $\begin{array}{c}\text { Mellon mass } \\
(\mathrm{g})\end{array}$ & $\begin{array}{c}\text { Water added } \\
(\mathrm{ml})\end{array}$ & $\begin{array}{c}\text { Time of soaking } \\
(\mathrm{min})\end{array}$ & $\begin{array}{c}\text { Shelling } \\
\text { performance }\end{array}$ \\
\hline 20 & 7.5 & 5 & $50.75 \%$ \\
20 & 7.5 & 7 & $56.25 \%$ \\
20 & 7.5 & 10 & $44.59 \%$ \\
20 & 7.5 & 15 & $60.32 \%$ \\
\hline
\end{tabular}

Table 1d. Shelling performance variation with time using $10.0 \mathrm{ml}$ added water.

\begin{tabular}{c|c|c|c}
\hline $\begin{array}{c}\text { Melon mass } \\
(\mathrm{g})\end{array}$ & $\begin{array}{c}\text { Water added } \\
(\mathrm{ml})\end{array}$ & $\begin{array}{c}\text { Time of soaking } \\
(\mathrm{min})\end{array}$ & $\begin{array}{c}\text { Shelling } \\
\text { performance }\end{array}$ \\
\hline & & & \\
20 & 10.0 & 5 & $49.35 \%$ \\
20 & 10.0 & 7 & $62.96 \%$ \\
20 & 10.0 & 10 & $57.53 \%$ \\
20 & 10.0 & 15 & $52.83 \%$ \\
\hline
\end{tabular}

Table 1e. Shelling Performance variation with time using $12.5 \mathrm{ml}$ added water.

\begin{tabular}{c|c|c|c}
\hline $\begin{array}{c}\text { Melon mass } \\
(\mathrm{g})\end{array}$ & $\begin{array}{c}\text { Water added } \\
(\mathrm{ml})\end{array}$ & $\begin{array}{c}\text { Time of soaking } \\
(\mathrm{min})\end{array}$ & $\begin{array}{c}\text { Shelling } \\
\text { performance }\end{array}$ \\
\hline & & & \\
20 & 12.5 & 5 & $43.65 \%$ \\
20 & 12.5 & 7 & $59.42 \%$ \\
20 & 12.5 & 10 & $46.97 \%$ \\
20 & 12.5 & 15 & $43.02 \%$ \\
\hline
\end{tabular}

\subsection{Variation of Shelling Performance with Moisture Content}

The results for the determination of soaking time are shown in Table 2 and Figure 3. It was observed that at a moisture content of $23.08 \%$, maximum shelling efficiency was obtained at a fixed drum speed of $350 \mathrm{rpm}$.

\subsection{Variation of Shelling Performance with Drum Speed}

Table 3 and Fig. 4 show the result of variation of shelling performance with increasing drum speed. It was observed that shelling performance was best at a speed of $350 \mathrm{rpm}$.

Based on the experimental data obtained in Tables 1a, b, c, $\mathrm{d}$ and $\mathrm{e}$, it was discovered that time of soaking played an important role in melon shelling performance. The higher the time of soaking, the better the shelling performance but at the soaking time in which the maximum retention capacity is reached, the lower the shelling performance.

From Tables 1 and 2, the higher the moisture content, the greater the shelling performance but as the maximum water retention capacity of melon is reached, the shelling performance starts to decrease.

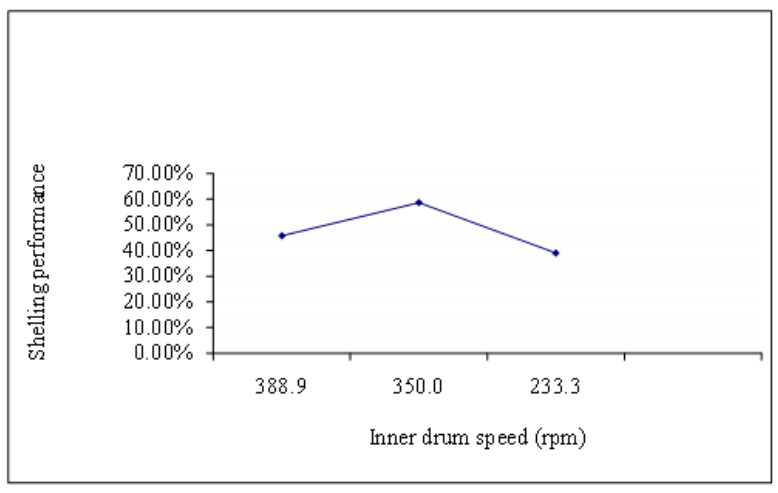

Figure 4. Graph of shelling performance against inner drum speed( from Table 3) 


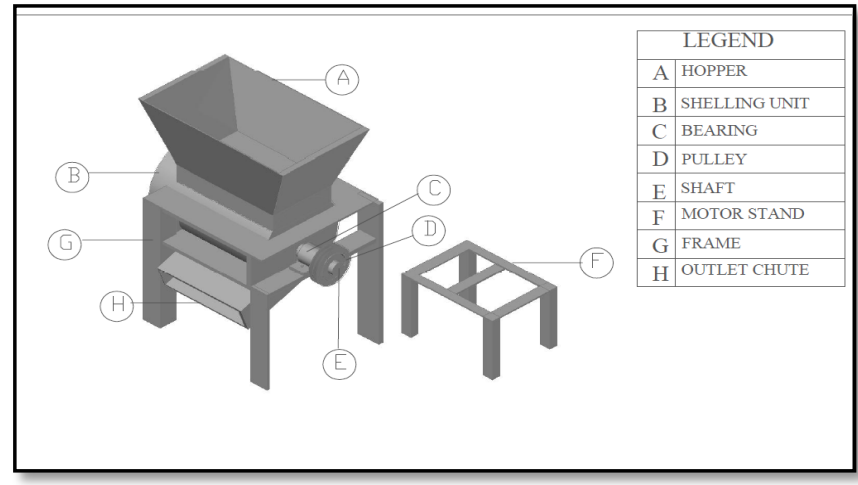

Figure 5. Complete Melon Sheller

From experimental data in Table 3, it was discovered that the speed of rotation of inner drum is another factor that affects the shelling performance. It was noted that at lower speeds, the shelling performance was better than operating at high speed. Shelled and unshelled melon seeds were broken at high speed. This breakage can be attributed to the subjection of the seeds to stresses exceeding their maximum resistance.

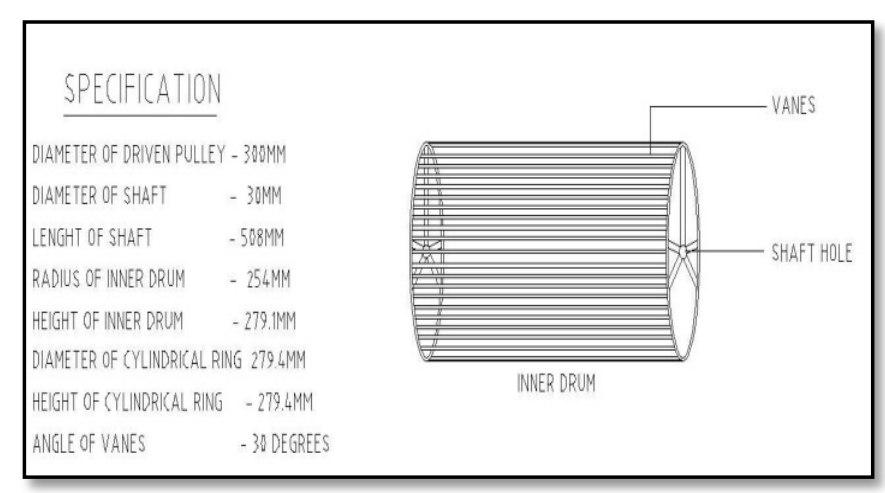

Figure 6. Complete inner drum

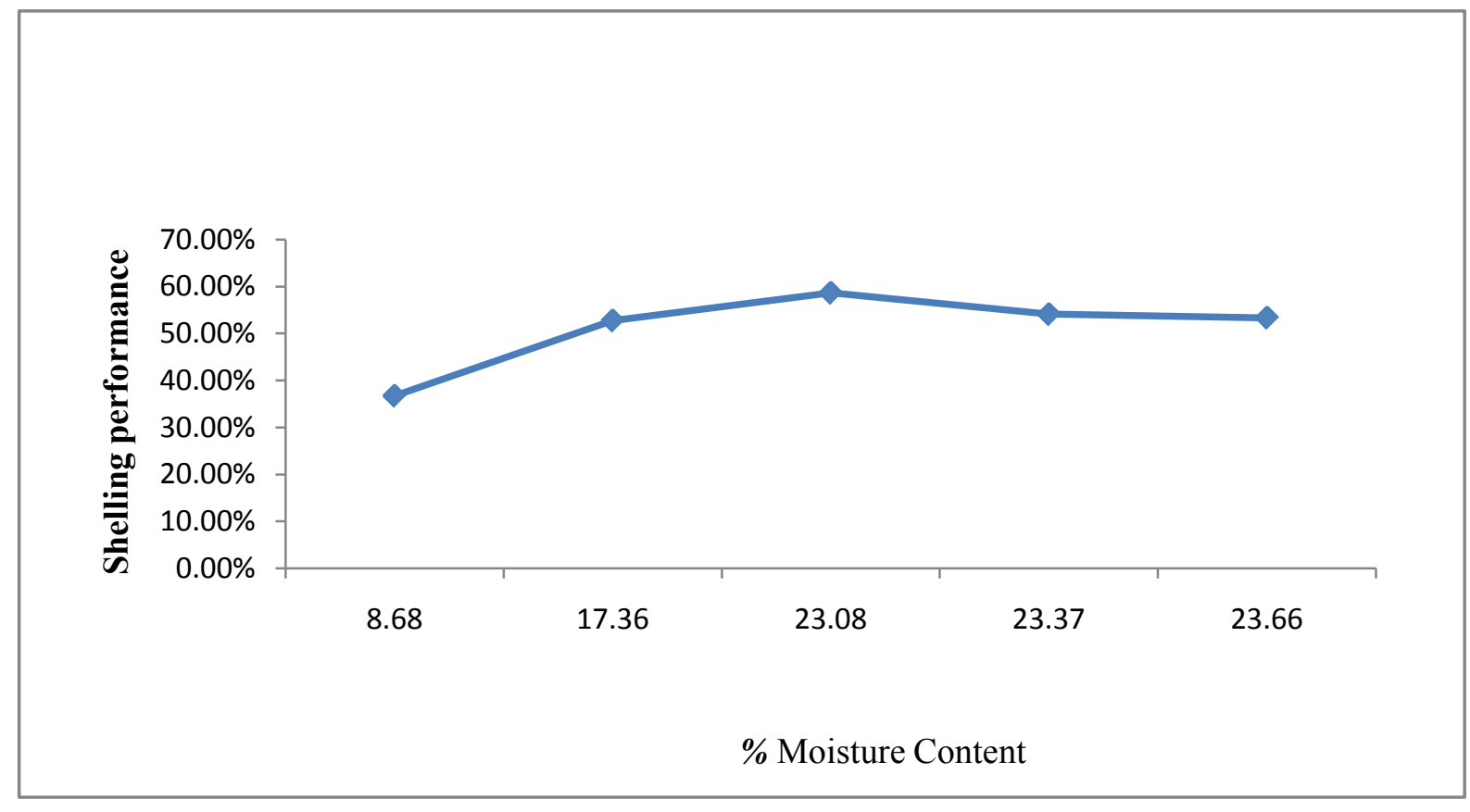

Figure 3. Graph of shelling performance against $\%$ moisture content taken from table 2

Table 2. Shelling Performance variation with Moisture Content under fixed time constraint and fixed drum speed of 350rpm.

\begin{tabular}{c|c|c|c|c|c|c|c|c}
\hline $\begin{array}{c}\text { Initial } \\
\text { mass (g) }\end{array}$ & $\begin{array}{c}\text { Water } \\
\text { added (ml) }\end{array}$ & $\begin{array}{c}\text { Soaking } \\
\text { Time (min) }\end{array}$ & $\begin{array}{c}\text { Final } \\
\text { mass (g) }\end{array}$ & $\begin{array}{c}\text { \% Moisture } \\
\text { Content }\end{array}$ & $\begin{array}{c}\text { Total mass } \\
\text { from outlet unit (g) }\end{array}$ & $\begin{array}{c}\text { Total mass } \\
\text { shelled (g) }\end{array}$ & $\begin{array}{c}\text { Shelling } \\
\text { Performance }\end{array}$ & $\begin{array}{c}\text { Percentage } \\
\text { Loss }\end{array}$ \\
\hline 20 & 2.5 & 7 & 21.9 & 8.68 & 17.7 & 6.5 & $36.72 \%$ & 11.50 \\
20 & 5 & 7 & 24.2 & 17.36 & 16.3 & 8.6 & $52.76 \%$ & 18.50 \\
20 & 7.5 & 7 & 26 & 23.08 & 16.7 & 9.8 & $58.68 \%$ & 16.50 \\
20 & 10 & 7 & 26.1 & 23.37 & 17 & 9.2 & $54.12 \%$ & 15.00 \\
20 & 12.5 & 7 & 26.2 & 23.66 & 16.3 & 8.7 & $53.37 \%$ & 18.50 \\
\hline
\end{tabular}

Table 3. Shelling performance variation with inner drum rotation speed

\begin{tabular}{c|c|c|c|c|c|c|c}
\hline $\begin{array}{c}\text { Pulley } \\
\text { size } \\
(\mathrm{mm})\end{array}$ & $\begin{array}{c}\text { Inner } \\
\text { drum speed } \\
(\mathrm{rpm})\end{array}$ & $\begin{array}{c}\text { Melon } \\
\text { mass } \\
(\mathrm{g})\end{array}$ & $\begin{array}{c}\text { Soaking } \\
\text { time } \\
(\mathrm{min})\end{array}$ & $\begin{array}{c}\text { Total mass } \\
\text { from } \\
\text { outlet unit }(\mathrm{g})\end{array}$ & $\begin{array}{c}\text { Total mass } \\
\text { shelled } \\
(\mathrm{g})\end{array}$ & $\begin{array}{c}\text { Shelling } \\
\text { performance }(\%)\end{array}$ & $\begin{array}{c}\text { Percentage } \\
\text { loss }\end{array}$ \\
\hline 300 & 233.3 & 20 & 7 & 16.6 & 7.6 & 45.78 & 17.00 \\
200 & 350 & 20 & 7 & 16.7 & 9.8 & 58.68 & 16.70 \\
180 & 388.9 & 20 & 7 & 16.4 & 6.4 & 39.02 & 18.00 \\
\hline
\end{tabular}




\section{Conclusions}

A shelling performance of $58.68 \%$ was achieved at percentage moisture of 23.08 using an inner drum rotation speed of $350 \mathrm{rpm}$ powered by a $1.0 \mathrm{Hp}, 1400 \mathrm{rpm}$ electric motor. A relatively low inner drum rotation speed was required to shell melon seeds effectively.

\section{REFERENCES}

[1] Adekunle A.S., Ohijeagbon I.O., and Olusegun H.D.,( 2009) Development and Evaluation of manually and motorized operated melon shelling machine using Impact force. A journal of Engr Sci and Tech, 2(1) 12-17.

[2] Akintunde B.O, Oyawale F.A and Tunde- Akintunde T.Y (2005) Design and Fabrication of a Cassava Peeling Machine. Nigerian Food Journal 23: 231-238

[3] ASAE Standard. (1982) S. 352. Moisture measurement-grains and seeds. St.Joseph, Michigan.Badifu G.I.O., Ogunsua, A.O.( 1991) Chemical composition of kernels from some species of cucurbitaceae grown in Nigeria. Plant foods human nutrition. 41: $35-44$.

[4] Enujuigha, V.N., Ayodele, O.O. (2003) Evaluation of nutrients and some anti nutrients in lesser-known, underutilized oils seeds. International journal of food science and technology 38(5), $525-528$

[5] Khurmi, R.J and Gupta, J.K., (2005) A textbook of machine design, New Delhi-110055, Eurasia Publishing House.

[6] Lagoke S.T.O., Chandra-Singh D.T. and Ologunde O.O. (1983) Pre-Emergence chemical weed control in 'egusi' melon in the Southern Guinea Savanna of Nigeria. Journal of crop protection. 2(2): $235-242$.

[7] Makanjuola G.A, (1972) A study of some of the physical properties of melon seeds. Journal of Agricultural Engineering Research, 17 (1): 128 - 137.

[8] Oladejo O.M., (2010) 'Effect of impact force and moisture content on the efficiency of melon sheller'. Msc thesis presented to Mechanical Engineering Dept, university of Ibadan. 